\title{
GoOd FAith ANd The TRIPS AgreEment: PUTting FleSh ON THE BONES OF THE TRIPS 'OBJECTIVES'
}

\begin{abstract}
Alison Slade ${ }^{1}$
I. INTRODUCTION

Article 7 of the Agreement on Trade Related Aspects of Intellectual Property Right (TRIPS Agreement) ${ }^{2}$ is entitled 'Objectives' and states that: -

The protection and enforcement of intellectual property rights should contribute to the promotion of technological innovation and to the transfer and dissemination of technology, to the mutual advantage of producers and users of technological knowledge and in a manner conducive to social and economic welfare, and to a balance of rights and obligations.
\end{abstract}

It is clear from this provision that the protection and enforcement of intellectual property rights aims to serve the broader interests of society by encouraging innovation and the transfer of that knowledge to others. Yet, Article 7 reflects more than just the

\footnotetext{
${ }^{1}$ Brunel Law School, Brunel University, London. I would like to thank Professor Graeme Dinwoodie, Dr Justine Pila and Ignacio de la Rasilla del Moral for their extensive and valuable comments on earlier drafts. I would also like to thank the delegates at the Conference on International Aspects of Intellectual Property Rights held at Arizona State University in December 2012 for their observations on a paper presented on this topic. As always, any errors or omissions are my own.

${ }^{2}$ (adopted 15 April 1994, entered into force 1 January 1995) 1869 UNTS 299.
} 
intellectual property 'bargain' within the international arena. Supported by Article 8 and the preamble to the Agreement, Article 7 would appear to confirm that broader social and economic development interests are of vital concern to the Agreement and its negotiators. ${ }^{3}$ The balance of interests between producers and users is to be mutually advantageous; rights and obligations arising both within and beyond the Agreement are to be appropriately reconciled; and socio-economic welfare more generally is to be a guiding objective for all TRIPS compliant regimes. Both Article 7 and its neighbour Article 8 have long been promoted as key to introducing a more balanced perspective to intellectual property protection at the international level, thereby forming the lens through which other provisions of the Agreement are to be defined. ${ }^{4}$ This perspective

\footnotetext{
${ }^{3}$ Article 8, entitled 'Principles', states that: -
}

1. Members may, in formulating or amending their laws and regulations, adopt measures necessary to protect public health and nutrition, and to promote the public interest in sectors of vital importance to their socio-economic and technological development, provided that such measures are consistent with the provisions of this Agreement.

2. Appropriate measures, provided that they are consistent with the provisions of this Agreement, may be needed to prevent the abuse of intellectual property rights by rights holders or the resort to practices which unreasonably restrain trade or adversely affect the international transfer of technology.

The preamble, for example, 'Recognis[es] the underlying public policy objectives of national systems for the protection of intellectual property, including developmental and technological objectives.'

${ }^{4}$ Many WTO Member States, in particular developing countries, have sought to rely on Article 7 (and Article 8) to argue that the TRIPS Agreement should be interpreted and implemented in a manner that is more sensitive to the wider socio-economic and development goals of developing nations. Graeme B Dinwoodie and Rochelle C Dreyfuss, A Neofederalist Vision of TRIPS: The Resiliance of the International Intellectual Property Regime (OUP 2012) 109-111; Peter K Yu, 'The Objectives and 
makes Articles 7 and 8 vital components of the interpretative process. However, the legal relevance of Article 7 has been somewhat limited by the perceived ambiguities of its language. ${ }^{5}$ This may have undermined its legal recognition, with Article 7 being afforded only limited recognition from the Dispute Settlement Body (DSB) of the World Trade Organisation (WTO). In fact, relatively few disputes involving the TRIPS Agreement have been brought before the DSB and only a small number of the resulting reports actually mention Articles 7 and/or $8 .{ }^{6}$ Yet, despite the limited material upon which to draw, it is possible to identify two seemingly distinct approaches to these provisions.

Principles of the TRIPS Agreement' (2009) 46 Houston L. Rev. 979, 1022; Carlos M Correa, Trade Related Aspects of Intellectual Property Rights: A Commentary on the TRIPS Agreement (OUP 2007) 93. ${ }^{5}$ Thomas F. Cotter, 'Market Fundamentalism and the TRIPS Agreement' (2004-2005) 22 Cardozo Arts \& Ent. L.J. 307, 327. Cotter argues that the vagueness of the language used should not necessarily undermine their legal application given that many legal concepts are somewhat vague, for example that of due process.

${ }^{6}$ Total number of complaints proceeding to a Panel ruling is ten, with two of the complaints being on the same facts (thus only eight distinct factual situations have been ruled upon). Three have been appealed to the Appellate Body and decisions issued. For a more detailed analysis of the WTO TRIPS disputes see Edward Lee, 'Measuring TRIPS Compliance and Defiance: The WTO Compliance Scorecard' (2011) 18 J. Intell. Prop. L. 401; Joost Pauwelyn, ‘The Dog that Barked but Didn’t Bite: 15 Years of Intellectual Property Disputes at the WTO', (2010) 1 J. Int. Disp. Settlement 389, 393-396. The number of Panel rulings is about to change. Both the Ukraine and Honduras have requested the establishment of a Panel to hear their complaints against the plain packing rules for tobacco products recently implemented in Australia. WTO, Australia: Certain Measures Concerning Trade Marks and other Plain Packaging Requirements Applicable to Tobacco Products and Packaging - Request for the Establishment of a Panel by Ukraine (17 August 2012) WT/DS434/11; Request for the Establishment of a Panel by Honduras (17 October 2012) WT/DS435/16. 
In the first line of decisions, the tribunals adopt a position that identifies Article 7, as well as Article 8, as mere expressions of the inherent characteristics of the international intellectual property system. In this role these provisions have little, if any, legal value in their own right. For example, the panel in Canada-Patent Protection of Pharmaceutical Products ${ }^{7}$ appears to accept that both Articles 7 and 8 are simply illustrative of the balancing of goals that had already occurred during treaty negotiations, and thus irrelevant for defining the scope of other provisions of the Agreement.

However, a second line of decisions adopts a contrary perspective by acknowledging that Articles 7 and 8 may have a legally active function within the TRIPS regime. The Appellate Body in Canada - Term of Patent Protection leaves the door open for their future application by acknowledging that: -

[O]ur findings in this appeal do not in any way prejudge the applicability of Article 7 or Article 8 of the TRIPS Agreement in possible future cases with respect to measures to promote the policy objectives of the WTO Members that are set out in those Articles. Those Articles still await appropriate interpretation. $^{8}$

\footnotetext{
${ }^{7}$ WTO, Canada: Patent Protection of Pharmaceutical Products - Report of the Panel (17 March 2000)

WT/DS114/R (Canada - Pharmaceuticals).

${ }^{8}$ WTO, Canada: Term of Patent Protection - Report of the Appellate Body (18 September 2000)

WT/DS170/AB/R (Canada - Patent Term) [101].
} 
Yet, it is the decision in United States - Section 211 Omnibus Appropriations Act of 1998 that is most significant in delineating a future role for Article $7 .{ }^{9}$ Here the Panel takes the first steps in defining how this provision should be interpreted by identifying Article 7 as 'a form of the good faith principle.' In this regard, the Panel report provides an important explanation of the function of Article 7 that was not disavowed by the Appellate Body in its final report. By identifying Article 7 as 'a form of the good faith principle', the Panel expressly introduces into the TRIPS Agreement a good faith obligation for all WTO Member States when implementing TRIPS, and a good faith obligation for all those interpreting the Agreement.

The good faith principle has been recognised within international law as incorporating concepts beyond the mere subjective belief of a party to a dispute ${ }^{10}$ and is of greater influence than the vague, 'open-ended' ancillary notions of good faith that could equally be replaced with other equally general terms such as 'reasonableness' or 'fairness'. ${ }^{11}$ Within international law, good faith acquires most significance as a general

\footnotetext{
${ }^{9}$ WTO, United States: Section 211 Omnibus Appropriations Act of 1998 - Report of the Panel (6 August 2001) WT/DS176/R (US - s211).

${ }^{10}$ Robert Kolb, 'Principles as Sources of International Law (with Special Reference to Good Faith)' (2006) Netherlands Int'l L. Rev. 1, 14-16.

${ }^{11}$ Ibid 16-17. The author equates the concept of good faith with legal 'standards' that operate to 'bridge the gap' between the facts of the case and the applicable norm, where the norm in question does not directly address the specifics of the case in hand. Whilst Kolb does not perceive this to be the most important role for good faith he does recognise that this role can lead to the creation of autonomous standards that act as a source of law. The suggestion being that good faith, as a general legal standard, can facilitate the creation of legally applicable equitable values.
} 
principle of law and a principle of customary international law ${ }^{12}$ that, as recognised by the Appellate Body in United States - Import Prohibition of Certain Shrimp and Shrimp Products, 'controls the exercise of rights by states.' ${ }^{13}$ This general principle has, over time, spawned a more precise series of international obligations and corresponding rights for both states and international organisations. ${ }^{14}$ And whilst the WTO Appellate Body has shown reluctance to establish that a Member has failed to act in good faith, ${ }^{15}$ it has demonstrated a willingness to review a Member State's actions for compliance with the principle, especially where textual support for such an approach can be found within the WTO Agreements themselves. ${ }^{16}$ Several provisions have been identified by the Panel and the Appellate Body as implying a good faith obligation or as expressing the principle of good faith, these include the chapeau of Article XX of the General Agreement on Tariffs and Trade 1994 (GATT); ${ }^{17}$ the term 'objective examination' in Article 3.1 of the Agreement on Implementation of Article VI of the General

\footnotetext{
${ }^{12}$ Schwarzenberger describes good faith as one of the 'seven fundamental principles' of international law, Georg Schwarzenberger and E D Brown, A Manual of International Law, 6th edition (London, 1969) 35-36. The international Court of Justice has described the principle of good faith as 'One of the basic principles governing the creation and performance of legal obligations, whatever their source. Nuclear Tests Case (Australia v France) [1974] ICJ Rep 253, 268. Marion Panizzon, Good Faith in the Jurisprudence of the WTO (Schulthess, Oxford 2006) 11-20.

${ }^{13}$ WTO, United States: Import Prohibition of Certain Shrimp and Shrimp Products - Report of the Appellate Body (12 October 1998) WT/DS58/AB/R [158] (US - Shrimp)

${ }^{14}$ Andrew D Mitchell, 'Good Faith in WTO Dispute Settlement' (2006) 7 Melb. J. Int'1 L. 339, 345.

${ }^{15}$ For an analysis of the Appellate Body's approach towards the good faith principle see Panizzon (n 11) chapter 8 .

${ }^{16}$ US - Shrimp (n 12) [156]-[186].

${ }^{17}$ Ibid, [158].
} 
Agreement on Tariffs and Trade 1994 (Anti-Dumping Agreement), ${ }^{18}$ paragraph 2 of Annex II to the Anti-Dumping Agreement; ${ }^{19}$ and, most importantly for this study, Article 7 of the TRIPS Agreement. This is a significant development. Whilst, the TRIPS Agreement does make explicit reference to the requirement of 'good faith' at several points, ${ }^{20}$ none of these provisions impose a good faith obligation directly upon Member States. They are concerned only with ensuring that the activities of individuals within the state satisfy a requirement of good faith. ${ }^{21}$ As a result, it is the Panel's interpretation of Article 7 which expressly imposes the first good faith obligation of the TRIPS Agreement for Member States. ${ }^{22}$

The implications of this decision are important in relation to both the role of the good faith principle within the TRIPS Agreement and the function of Article 7. First, this decision accepts that the operationalisation of Article 7 is to arise through the application of good faith jurisprudence, thereby establishing Article 7 as the legal basis for the good faith obligation. Secondly, it shapes our understanding of good faith in the context of the TRIPS Agreement. As a form of the good faith principle, Article 7 acts as

\footnotetext{
${ }^{18}$ WTO, United States: Anti-Dumping Measures on Certain Hot-Rolled Steel Products from JapanReport of the Appellate Body (24 July 2001) WT/DS184/AB/R [193].

${ }^{19}$ Ibid [101]. For an analysis of the reasoning of the WTO Appellate Body on the issue of good faith see Helge Elisabeth Zeitler, “Good Faith' in the WTO Jurisprudence: Necessary Balancing Element or an Open Door to Judicial Activism?’ (2005) 8 J. Int'l Econ. L. 721, 735-737; Panizzon (n 11) 51-60.

${ }^{20}$ The TRIPS Agreement makes explicit reference to the requirement of 'good faith' at articles 24.4, 24.5, 48.2 and 58(c). In addition, several provisions seek to prevent the 'abuse of intellectual property rights' and the abuse of intellectual property enforcement procedures, see articles 8.2, 40.2, 41.1, 48.1, 50.3 and 53.1.

${ }^{21}$ Mitchell (n 13) 353.

${ }^{22}$ Panizzon (n 11) 61.
} 
a safeguard against the potential arbitrary regulation of intellectual property by WTO Members. More particularly, this is achieved by importing into the TRIPS Agreement corollary good faith principles, such as abus de droit, legitimate expectations, and interpretative objectives such as the principle of effectiveness. In fact, in the legal application of good faith, Article 7 may actually take on a substantive role in defining the Agreement's terms and obligations. At the very least, the Panel decision in USs211 reinforces the importance of Article 7 as an interpretative tool and finally sees Article 7 acknowledged judicially as an effective source of legal obligations within the international intellectual property system. As will be demonstrated below, the recent complaints made by several WTO Member States against Australian legislation mandating plain packaging for tobacco products provides the ideal scenario to demonstrate the impact the US-s211 Panel's decision could and should have on future cases.

\section{UNITED STATES - SECTION 211 OMNIBUS APPROPRIATIONS ACT OF 1998}

The decision of the WTO Dispute Settlement Panel US - s 211 provides an interesting, but as yet under appreciated, ${ }^{23}$ explanation of the function of Article 7 of the TRIPS Agreement. This dispute was initiated by the European Communities to address the consistency of section 211 of the Omnibus Appropriations Act of 1998 with the obligations arising under the TRIPS Agreement and the Paris Convention for the

\footnotetext{
${ }^{23}$ For a brief discussion on the relevance of this decision see Henning Grosse Ruse-Khan, 'The (Non) Use of Treaty Object and Purpose in Intellectual Property Disputes in the WTO' in Sustainable Development Principles in the Decisions of International Courts and Tribunals 1992-2012 (CUP 2012) 20-25. http://papers.ssrn.com/sol3/papers.cfm?abstract_id=1939859 accessed 14 December 2013.
} 
Protection of Industrial Property (Paris Convention). ${ }^{24}$ The United States had introduced this provision to prevent the registration and enforcement of trade marks and trade names that had been confiscated by the Cuban government during the early 1960s.

The origins of the WTO dispute lay in a lengthy legal battle between two commercial organisations that both claimed trade mark and trade name protection for 'Havana Club' in the United States. In 1993, the French company, Pernod-Ricard, entered into a joint venture agreement with the Cuban government, forming Havana Club Holding $(\mathrm{HCH})$, in order to make and export rum worldwide under the Havana Club name. Four years later, Barcadi acquired the original proprietary interests in Havana Club from the Arechabala family, who had owned the business prior to its seizure by the Cuban government. During this period, Barcardi also successfully lobbied the US Congress to have section 211 included in the Omnibus Appropriations Act of 1998. The effect was to retroactively invalidate any rights by the Cuban Government or its assignees to the Havana Club trade mark in the United States. In an infringement action brought by $\mathrm{HCH}$, both the District Court of New York and the Court of Appeals for the Second Circuit held, inter alia, that section 211 prevented $\mathrm{HCH}$ from exercising any legal rights to the Havana Club name. ${ }^{25}$ In July 1999 the matter was advanced by the European Union before the WTO. The EU claimed that US legislation, in particular section 211 , actively discriminated against the trade mark

\footnotetext{
${ }^{24}$ Paris Convention for the Protection of Industrial Property (adopted 20 March 1883, last revised 14 July 1967, amended 28 September 1979) 828 UNTS 305.

${ }^{25}$ Havana Club Holding, S.A. v Galleon, S.A. 62 F.Supp.2d 1085 (NY 1999); Havana Club Holding, S.A. v Galleon, S.A. 203 F.3d 116 (2nd Cir. 2000).
} 
rights of certain foreign nationals and, therefore, was contrary to several provisions in both the TRIPS Agreement and the Paris Convention. ${ }^{26}$

In analysing the consistency of section 211 with WTO law, the Panel makes a significant contribution to our understanding of the role of Article 7 of the TRIPS Agreement and the function of the good faith principle within the TRIPS Agreement. The Report acknowledges that national legislation might arbitrarily regulate intellectual property ownership and, in that instance, Article 7 may act as a safeguard to protect against such abuse. The Panel notes that: -

[A]rticle 7 of the TRIPS Agreement states that one of the objectives is that "[t]he protection and enforcement of intellectual property rights should contribute...to a balance of rights and obligations." We consider this expression to be a form of the good faith principle. The Appellate Body in United States - Shrimps stated that this principle "controls the exercise of rights by states. One application of this principle, the doctrine widely known as the doctrine of abus de droit, prohibits the abusive exercise of a state's rights and enjoins that whenever the assertion of a right 'impinges on the field covered by [a] treaty obligation, it must be exercised bona fide, that is to say reasonably.' An abusive exercise by a Member of its own treaty right thus results in a breach of the treaty rights of the other members and, as well, a violation of the treaty obligation of the Member so acting." Members must therefore implement the provisions of the TRIPS

\footnotetext{
${ }^{26}$ Violation was claimed of TRIPS Articles $2.1,3.1,4,15.1,16.1$, and 42 in conjunction with violations under the Paris Convention, Articles 2(1), 6bis(1), 6quinquies A(1) and 8. US-s211 (n 8) [3.1]-[3.4].
} 


\section{Agreement in a manner consistent with the good faith principle enshrined in Article 7 of the TRIPS Agreement. ${ }^{27}$}

Notwithstanding a lack of explicit application of this reasoning by the $\operatorname{Panel}^{28}$ and an Appellate Body decision that does not directly address the relevance of Article $7,{ }^{29}$ the recognition of Article 7 as an expression of the good faith principle should heighten the profile of this provision and define the application of the good faith principle in the context of the TRIPS Agreement. As recognised by the International Court of Justice, 'One of the basic principles governing the creation and performance of legal obligations, whatever their source, is the principle of good faith. ${ }^{30}$ Although the

${ }^{27} U S-s 211$ (n 8) [8.57] (emphasis added). The panel quoted from the Appellate Body Report, US Shrimp (n 12) [158].

${ }^{28}$ In analysing the consistency of section 211 with article 15.1 of the TRIPS Agreement, the Panel accepts that article 15.2 allows Member States to deny registration on 'other grounds' including grounds relating to conditions of ownership. Beyond recognising that safeguards exist within the TRIPS Agreement to prevent potential abuse, the Panel makes no further attempt to scrutinize United States' law for compliance with the principle of good faith as enshrined in Article 7. US - s211 (n 8) [8.55]-[8.60]. ${ }^{29}$ WTO, United States: Section 211 Omnibus Appropriations Act of 1998 - Report of the Appellate Body (2 January 2002) WT/DS176/AB/R. In relation to art 15.1 of the TRIPS Agreement, the AB upheld the Panel's decision, confirming that WTO Members have the right to determine their own conditions of filing and registration, including those relating to ownership and the registration of confiscated marks. However, the $\mathrm{AB}$ overrules the Panel on several of its key findings, holding that the TRIPS Agreement obliges Member States to provide adequate protection for trade names; and that the US legislation violated the national treatment and most-favoured-nation principles as it applied only to Cuban nationals and not to nationals from the US or any other Member State.

${ }^{30}$ Nuclear Tests Case (n 11) [46]. 
principle of good faith is today understood to be included implicitly in international treaties, ${ }^{31}$ by expressly associating the principle with Article 7 the WTO Panel actually compels consideration of certain 'Objectives' as expressed within this provision when both implementing and interpreting the Agreement.

\section{ARTICLE 7 AND THE GOOD FAITH PRINCIPLE: DEFINING THE SCOPE OF THE OBLIGATION}

To fully understand the implications of the Panel's decision it is necessary, first, to delineate which of the objectives mentioned within Article 7 operate as an expression of the good faith principle and, secondly, to define the legal principles that operate to shape the scope of this good faith obligation.

In addressing the first issue, the Panel appears to qualify the boundaries of the good faith obligation contained within Article 7. This provision is entitled 'Objectives' in the plural, and explicitly requires that the protection and enforcement of intellectual property rights should contribute to 'the promotion of technological innovation'; 'the transfer and dissemination of technology'; 'the mutual advantage of producers and users of technological knowledge'; 'and in a manner conducive to social and economic welfare'; 'and to a balance of rights and obligations.' Although, the Panel requires that all Members must implement the provisions of the TRIPS Agreement in accordance with the principle of good faith enshrined in Article 7, it chose to only identify that 'the protection and enforcement of intellectual property rights should contribute to...a

\footnotetext{
${ }^{31}$ Antony D'Amato, 'Good Faith' in R. Bernhardt (ed), Encyclopaedia of Public International Law, Vol II (Elsevier 1995) 600.
} 
balance of rights and obligations' was a form of the good faith principle. We can therefore assume that the implied principle of good faith as identified by the Panel is limited to this phrase. It does not, as has been suggested, directly "impl[y] a good faith constraint on intellectual property rights where they might be seen to undermine the goal of "social and economic welfare."”,32 Thus, the balance envisaged by Articles 7 is limited to reconciling the competing rights and obligations arising under the TRIPS Agreement and not to invoking a broader range of interests from beyond the WTO texts. That being said, we should not rush to conclude that the application of this expression of good faith will not have a positive impact upon 'social and economic' welfare within Member States, as will be discussed in more detail below.

Turning to the second point above, in defining the application of this good faith obligation, the Panel draws upon the decision of the Appellate Body in US - Shrimp to affirm that the wider notion of good faith 'controls the exercise of rights by states' and that 'members must therefore implement the provisions of the TRIPS Agreement in a manner consistent with the good faith principle enshrined in Article 7. ${ }^{33}$ Here the Panel implicitly acknowledges that the good faith obligation imposed by Article 7 derives from a particular emanation of the wider good faith principle within treaty relations, that of pacta sunt servanda. ${ }^{34}$ In addition, the Panel goes on to identify the doctrine of

\footnotetext{
${ }^{32}$ Aditi Bagchi, 'Compulsory Licensing and the Duty of Good Faith in TRIPS' (2002-2003) 55 Stan. L. Rev 1529, 1542.

${ }^{33}$ US - s211 (n 8) (emphasis added).

${ }^{34}$ As noted by O'Connor, 'The principle of good faith in international law is a fundamental principle from which the rule pacta sunt servanda and other legal rules distinctively and directly related to honesty, fairness and reasonableness are derived.' John O'Connor, Good Faith in International Law (Aldershot, Dartmouth 1991) 124.
} 
abus de droit as being a particular application of the principle of good faith that 'prohibits the abusive exercise of a state's rights. ${ }^{, 35}$

What is more, flowing directly from the general principle of good faith and the rule of pacta sunt servanda is the principle of treaty interpretation in good faith, as codified in Article 31 of the Vienna Convention on the Law of Treaties $1969 .{ }^{36}$ As noted by Sinclair, 'If 'good faith' is required of the parties in relation to the observance of treaties, logic demands that 'good faith' be applied to the interpretation of treaties. ${ }^{, 37}$ Therefore, one cannot adequately consider the good faith obligations of Member States without an appreciation of the obligations that the principle of good faith creates for those that are employed to interpret the Treaty. As will be shown in the following discussion, Article 7, as a form of the good faith principle, encompasses both aspects of the good faith obligation - the regulatory and the interpretative. Moreover, by connecting the principle of good faith to Article 7 the Panel transforms this provision into the legal basis of the obligation. ${ }^{38}$ Consequently, by focussing on accepted good faith jurisprudence of the WTO a clearer picture emerges as to the correct 'balance of rights and obligations' required by Article 7, which ultimately helps to define the actual

${ }^{35} U S-s 211$ (n 8) [8.57].

${ }^{36}$ ILC, 'Yearbook of the International Law Commission 1966, Volume II' (1966) UN Doc A/CN.4/SER.A/1966/Add.1, 221 [12].

${ }^{37}$ Ian Sinclair, The Vienna Convention on the Law of Treaties $\left(2^{\text {nd }}\right.$ edn, Manchester University Press 1984) 119. Also, as noted by the International Law Commission, 'the interpretation of treaties in good faith and according to law is essential if the pacta sunt servanda rule is to have any real meaning.' ILC (n 35) 119.

${ }^{38}$ Whether or not in an attempt to introduce important legal principles into the TRIPS Agreement without subjecting the WTO Dispute Settlement Body to accusations of judicial activism. See the discussion at page 34 . 
meaning and function of this provision. As will become apparent below, the requirement of a good faith interpretation of treaties; the doctrine of abus de droit; and the principle of legitimate expectations, all work to inform our understanding of the application of the good faith principle within the confines of the TRIPS Agreement.

\section{A. Article 7: A Benchmark for Compliance with Pacta Sunt Servanda.}

The obligation for Member States to conduct treaty relations in good faith is well established within international law. This fundamental legal principle has been codified in the Vienna Convention on the Law of Treaties, which states that 'Every treaty in force is binding upon the parties to it and must be performed by them in good faith., ${ }^{39}$ Accordingly, the principle of pacta sunt servanda 'determines and offers an authoritative regulation for the parties' conduct. ${ }^{40}$ With regard to treaties 'in force', it not only creates a legal obligation for member states to put into effect the rules and principles arising under the treaty, but to do so in good faith. This requires States to implement their obligations in a way that pays due respect to the purpose of the treaty, so that the intentions of the Parties can be realised. ${ }^{41}$ Consequently, Member States must refrain from any action which would defeat a treaty’s object and purpose. ${ }^{42}$

\footnotetext{
${ }^{39}$ Vienna Convention on the Law of Treaties (adopted 23 May 1969, entered into force 27 January 1980) art 26.

${ }^{40}$ Mark E Villiger, Commentary on the 1969 Vienna Convention on the Law of Treaties, (Martinus Nijhoff, 2009) 365 .

${ }^{41}$ The Gabčikovo-Nagymaros Project (Hungary/Slovakia) (Judgement) [1997] ICJ Rep 7, 78-79.
} 
The Panel in US-s211 states that 'Members must implement the provisions of the TRIPS Agreement in a manner consistent with the good faith principle enshrined in Article 7 of the TRIPS Agreement' thereby expressly incorporating the principle of pacta sunt servanda into the TRIPS Agreement. This in itself is not a significant development given that the WTO Appellate Body has already acknowledged the importance of the principle for the WTO Treaty. ${ }^{43}$ Yet, by connecting the principle to a specific TRIPS provision the Panel appears to sanction the use of Article 7 as a legal benchmark for regulating Member States behaviour for compliance with the good faith obligation. Thus, satisfaction of the good faith principle, in the context of the TRIPS Agreement, requires that 'the protection and enforcement of intellectual property rights should contribute to a balance of rights and obligations.' The practical implications of this development become apparent in the following analysis, when we examine the particular applications of the good faith principle that are both expressed and implied from the statement of the Panel in US-s211.

\section{B. 'A treaty shall be interpreted in good faith'}

If Members must implement their TRIPS obligations in accordance with the good faith principle enshrined within Article 7 it thus follows that those interpreting the rights and duties arising under the Agreement must do so in accordance with the good faith

\footnotetext{
${ }^{42}$ ILC (n 35) 211[4]; Zeitler (n 18) 730.

${ }^{43}$ The WTO Appellate Body has acknowledged that the principle of pacta sunt servanda forms an essential part of WTO jurisprudence. WTO, United States: Continued Dumping and Subsidy Offset Act of 2000 - Report of the Appellate Body (16 January 2003) WT/DS217/AB/R. The principle also finds expression in Article XVI.4 of the Agreement Establishing the World Trade Organisation.
} 
principle. Therefore the question arises as to what good faith interpretation in accordance with Article 7 of the TRIPS Agreement requires?

The legal text of the dispute settlement system of the WTO, the Understanding on Rules and Procedures Governing the Settlement of Disputes (DSU), ${ }^{44}$ provides that all WTO agreements are to be interpreted 'in accordance with customary rules of interpretation of public international law. ${ }^{45}$ The Appellate Body, in its first ever ruling, confirmed that the interpretative rules and principles of public international law, as expressed in the Vienna Convention on the Law of Treaties, are binding on the WTO when interpreting all covered agreements. ${ }^{46}$

Article 31.1 of the Vienna Convention, in codifying the 'General Rule of Interpretation', states that 'A treaty shall be interpreted in good faith in accordance with the ordinary meaning to be given to the terms of the treaty in their context and in light of its object and purpose.' Notwithstanding that Article 31 represents a single rule of treaty interpretation the process of its application is multifactorial. The formula that it establishes for treaty interpretation is made up of several key principles. First, the interpretation has to be in good faith. Secondly, the ordinary or natural meaning of the treaty terms is the presumed intention of the parties. Thirdly, the ordinary or natural meaning of the treaty term is to be determined in the context of the treaty and in light of

\footnotetext{
${ }^{44}$ (adopted 15 April 1994, entered into force 1 January 1995) 1869 UNTS 401.

${ }^{45}$ Ibid, art 3.2.

${ }^{46}$ WTO, United States: Standards for Reformulated and Conventional Gasoline - Report of the Appellate Body (29 April 1996) WT/DS2/AB/R, 15-16.

In fact, the Appellate Body has been willing to overturn Panel decisions for misapplying the interpretative rules of the Vienna Convention, WTO, India: Patent Protection for Pharmaceutical and Agricultural Chemical Products - Report of the Appellate Body (19 December 1997) WT/DS50/AB/R [43]-[48].
} 
its object and purpose. Both the first and the last aspects of Article 31.1 link the analysis of treaty interpretation to Article 7: a) Article 7 is a form of the good faith principle and b) Article 7, together with its neighbour Article 8 entitled 'Principles', are important indicators of the object and purpose of the TRIPS Agreement. As reaffirmed by the 2001 Ministerial Declaration on the TRIPS Agreement and Public Health, 'each provision of the TRIPS Agreement shall be read in the light of the object and purpose of the Agreement as expressed, in particular, in its objectives and principles. ${ }^{47}$ The reference to 'objectives' and 'principles' has been taken as explicit recognition of the role that both Articles 7 and 8 can play in the interpretative process. This role is heightened for Article 7 in being an expression of the good faith principle.

Good Faith Interpretation: A 'Holistic' Analysis

A good faith interpretation in accordance with Article 31.1 of the Vienna Convention can be identified as one that takes a holistic approach to the interpretative process. Thus good faith interpretation can be seen to incorporate two characterisations of the term holistic; 1) An interpretation that pays due respect to all the key elements enshrined in Article 31.1 ; 2) An interpretation that gives meaning and effect to all the terms of a treaty.

The three key principles of Article 31.1 - good faith, ordinary meaning, context and object and purpose - are understood to be of equal value in the interpretative

${ }^{47}$ WTO, 'Declaration on the TRIPS Agreement and Public Health - Adopted on 14 November 2001' November 2001) WT/MIN(01)/DEC/2 [5(a)]. See also the Doha Ministerial Declaration which requires the Council for TRIPS, in pursuing its work programme, to be guided by Articles 7 and 8 . WTO, 'Ministerial Declaration - Adopted on 14 November 2001' (20 November 2001) WT/MIN(01)/DEC/1 [19]. 
process with neither principle taking precedence over the other. ${ }^{48}$ Therefore the correct interpretative approach makes an integrated analysis of all the required elements. This holistic approach to Article 31 has been confirmed by Appellate Body. ${ }^{49}$ In fact, it has more recently acknowledged that the rules and principles of treaty interpretation are 'connected and mutually reinforcing components of a holistic exercise' such that 'the enterprise of interpretation is intended to ascertain the proper meaning of the provision; one that fits harmoniously with the terms, context and object and purpose of the treaty. ${ }^{50}$

That being said, it is clear that good faith has an overarching role within Article 31 and its application within the WTO. Good faith indicates to the interpreter how the function is to be carried out. ${ }^{51}$ It has been described by the Panel as 'a core principle of interpretation of the WTO Agreement ${ }^{52}$ and by the Appellate Body as 'inform[ing] a treaty interpreter's task. ${ }^{53}$ The pre-eminence of good faith is maintained by its primary position within the General Rule of Interpretation in Article $31-A$ treaty shall be

\footnotetext{
${ }^{48}$ ILC (n 35) 219-220.

${ }^{49}$ WTO, European Communities: Customs Classification of Frozen Boneless Chicken Cuts - Report of the Appellate Body (12 September 2005) WT/DS269/AB/R \& WT/DS286/AB/R [176].

${ }^{50}$ WTO, United States: Continued Existence and Application of Zeroing Methodology - Report of the Appellate Body (4 February 2009) WT/DS350/AB/R, [268] \& [273]. This is seen by many commentators as a move away from the 'text first' approach that the WTO has historically favoured. Brian Mercurio and Mitali Tyagi, 'Treaty Interpretation in the WTO Dispute Settlement: The Outstanding Question of the Legality of Local Working Requirements' (2010) 19 Minn. J. Int'l L. 275, 304.

${ }^{51}$ Richard K Gardiner, Treaty Interpretation (OUP 2010) 152.

${ }^{52}$ WTO, United States: Measures Affecting the Cross-Border Supply of Gambling and Betting Services Report of the Panel (10 November 2004) WT/DS285/R, [6.50].

${ }^{53}$ US - Offset Act (n 42) [296].
} 
interpreted in good faith... ${ }^{54}$ This ensures that it has application across the entire interpretative process informing considerations of ordinary meaning, object and purpose, and subsequent developments between the parties. ${ }^{55}$ Moreover, an interpretation that gives effect to all the principles enshrined in Article 31.1 of the Vienna Convention can be described as an interpretation in accordance with the 'good faith' principle. This is a characterisation of holistic that can be described as 'good faith' interpretation and thus in accordance with Article 7.

A second characterisation of holistic interpretation in good faith can also be identified. From the very beginnings of the Vienna Convention, good faith interpretation, in accordance with the other elements expressed within Article 31.1, has been linked to other interpretative principles, most notably that of effectiveness (ut res magis valeat quam pereat). ${ }^{56}$ This has allowed a general understanding to be drawn as to the content of interpretative good faith. 'Effective' interpretation is seen as one which gives meaning and effect to all terms of a treaty. It is a principle that has been acknowledged by the WTO: -

A fundamental tenet of treaty interpretation flowing from the general rule of interpretation set out in Article 31 is the principle of effectiveness (ut res magis valeat quam pereat). In United States - Standards for Reformulated and Conventional Gasoline, we noted that "[o]ne of the corollaries of the 'general rule of interpretation' in the Vienna Convention is that interpretation must give meaning and effect to all the terms of the treaty. An interpreter is

\footnotetext{
${ }^{54}$ Villiger (n 39) 425.

${ }^{55}$ Sinclair (n 36) 120; Villiger (n 39) 426; Gardiner (n 50) 148.

${ }^{56}$ ILC (n 35) 219 [6]. For a brief discussion on the negotiating history in relation to the principle of effectiveness see Gardiner (n 50) 149-150.
} 
not free to adopt a reading that would result in reducing whole clauses or paragraphs of a treaty to redundancy or inutility". ${ }^{57}$

Hence, an interpretation that does not appreciate the holistic nature of a treaty, by ignoring provisions or failing to adequately interpret their relevance, may be identified as an interpretation that has not made in good faith. ${ }^{58}$

As noted by the Appellate Body above, the good faith corollary of effective interpretation is taken to emanate from Article 31.1 of the Vienna Convention. It has been directly linked to other elements of Article 31.1 specifically that of object and purpose. As noted in the Summary Records of the International Law Commission, an interpretation that is made in good faith and takes full account of the object and purpose of a treaty will logically always give meaning and effect to the text. ${ }^{59}$ Consequently, the two facets of holistic interpretation - all the elements of Article 31.1 applied to all the elements of a treaty - are interrelated such that interpretative practice that fails to consider a treaty's object and purpose would implicitly run counter to the principle of effectiveness and thus good faith. However, this is not to suggest that the International Law Commission or the WTO support use of Article 31.1 to encourage a true

\footnotetext{
${ }^{57}$ WTO, Japan: Taxes on Alcoholic Beverages - Report of the Appellate Body (4 October 1996) WT/DS8, 9 \& 10/AB/R, 10-11 (citations omitted).

${ }^{58}$ In United States - s211 the Appellate Body utilised the principle of effectiveness to support an interpretation of the TRIPS Agreement that would not deprive a provision of the Paris Convention of meaning and effect. $U S-s 211$ (n 28) [338].

${ }^{59}$ ILC, 'Yearbook of the International Law Commission 1964, Volume I' (1964) UN Doc A/CN.4/SER.A/1964, 288-291.
} 
teleological approach to interpretation. ${ }^{60}$ The text of the treaty, in reflecting the common intentions of the parties, is of primary importance. Nevertheless, its ordinary meaning can only be established in light of a wider analysis of context, and object and purpose. $^{61}$

Returning to the TRIPS Agreement, it is fair to say that WTO tribunals have often failed to give full effect to 'good faith' interpretation. There has been a clear tendency to ignore key elements of the General Rule of interpretation as articulated in Article 31.1, which thereby results in sections of the TRIPS Agreement being reduced to inutility, in particular Articles 7 and 8. Despite being asked to directly engage with the all aspects of Article 31.1 of the Vienna Convention, in particular the 'object and purpose' of the TRIPS Agreement, the Panel in Canada - Pharmaceuticals made, what is generally perceived to be, an inadequate application of the principles of treaty interpretation. ${ }^{62}$

\footnotetext{
${ }^{60}$ The ILC stated that 'Properly limited and applied the maxim [ut res magis valeat quam pereat] does not call for an 'extensive' or 'liberal' interpretation in the sense of an interpretation going beyond what is expressed or necessarily to be implied in the terms of the treaty. ILC (n 35) 219 [6]; Interpretative practise of the WTO is governed by the DSU, which states that 'Recommendations and rulings of the DSB cannot add to or diminish the rights and obligations provided in the covered agreements.' DSU, art 3.2 (n 43).

${ }^{61}$ Gardiner (n 50) 152.

${ }^{62}$ Daya Shanker, 'The Vienna Convention on the Law of Treaties, the Dispute Settlement System of the WTO and the Doha Declaration on the TRIPS Agreement' (2002) 36 J. World Trade 721; Robert Howse, 'The Canadian Generic Medicines Panel: A Dangerous Precedent in Dangerous Times' (2005) 3 J. World Intell. Prop. J 493; Susy Frankel, 'WTO Application of 'the Customary Rules of Interpretation of Public International Law' to Intellectual Property' (2005/2006) 46 Va. J. Int'l L. 365; Hiroko Yamane, Interpreting TRIPS: Globalisation of Intellectual Property, Rights and Access to Medicine (Hart
} Publishing 2011). 
This dispute centred around two sections of the Canadian Patent Act, in force at the time. The first provision allowed third parties to carry out experiments on pharmaceutical products in order to gain regulatory approval for generic versions that were to be marketed on expiry of the patent. ${ }^{63}$ The second allowed third parties to manufacture and stock pile patented products for a period of six months prior to the expiry of the patent. ${ }^{64}$ In bringing the dispute, the EU argued that the Canadian patent regime breached several obligations of the TRIPS Agreement including the antidiscrimination rule in Article 27, the rights conferred on the patent owner in Article 28.1, and the term of patent protection required by Article $33 .{ }^{65}$

In response Canada maintained that these two provisions were legitimate exceptions authorised by the TRIPS Agreement, as they complied with the three criteria established by Article 30: -

i) the exception must be 'limited';

ii) the exception must not 'unreasonably conflict with the normal exploitation of the patent';

\footnotetext{
${ }^{63}$ Section 55.2(1) of the Patent Act.

${ }^{64}$ Section 55.2(2) of the Patent Act in conjunction with the 'Manufacturing and Storage of Patented Medicines Regulation'

${ }^{65}$ WTO, Canada: Patent Protection of Pharmaceutical Products - Request for the Establishment of a Panel by the European Communities (12 November 1998) WT/DS114/5.
} 
iii) the exception must not 'unreasonably prejudice the legitimate interests of the patent owner, taking into account the legitimate interests of third parties. ${ }^{66}$

Canada asserted that in interpreting Article 30, in accordance with the rule of treaty interpretation stated in Articles 31 and 32 of the Vienna Convention, particular attention should be given to Articles 7, 8.1, 1.1 and the first recital in the Preamble to the TRIPS Agreement. ${ }^{67}$

Despite this request, the Panel failed to make use of these important interpretative resources contained within the TRIPS Agreement itself, in particular Articles 7 and 8 . To fully appreciate how the WTO directly undermines the application of this main source of interpretative guidance it is necessary to review that Panel's approach in Canada-Pharmaceuticals and then consider how this could and should be rectified in the upcoming dispute against Australia - challenging rules mandating plain packaging for all tobacco products.

In Canada - Pharmaceuticals the Panel, in its interpretation of Article 30, chose to focus upon the impact the exception had upon the rights holder rather than make an analysis of the wider object and purpose of the Agreement, as incorporated inter alia within Articles 7 and $8 .^{68}$ This seems at odds with the very nature of an 'exception'

\footnotetext{
${ }^{66}$ Canada-Pharmaceuticals (n 6) [7.20].

${ }^{67}$ Canada-Pharmaceuticals (n 6) [4.13]-[4.20].

${ }^{68}$ Ruth L Okediji, 'Public Welfare and the Role of the WTO: Reconsidering the TRIPS Agreement'
} (2003) 17 Emory Int'1 L. Rev. 819, 914-15; Denis Barbosa, Margaret Chon and Andrés Moncayo von Hase, 'Sloughing Towards Development in International Intellectual Property' (2007) Mich. St. L. Rev. 71, 108 -109; Ruse-Khan (n 22) 27-32. 
which must exist only because there are other interests which take precedence over the interests of the patentee. ${ }^{69}$ Therefore, the nature of Article 30 required the Panel to examine the object and purpose of the Agreement to ascertain what interests might take priority.

The next appropriate application for object and purpose came when the Panel started to analyse the specific criteria governing the application of exceptions to patent rights. As mentioned above, Article 30 establishes three criteria that must be satisfied for an exception to be legitimate - it must be 'limited'; not 'unreasonably conflict with the normal exploitation of the patent'; and not 'unreasonably prejudice the legitimate interests of the patent owner.' If the Panel had taken an interest in the object and purpose of the Agreement, and thus Articles 7 and 8, many of the elements included in these provisions may have influenced the reasoning and maybe even the decision. Phrases such as 'mutual advantage of producers and users of technological knowledge' and 'in a manner conducive to social and economic welfare' together with the ability to 'adopt measures to protect public health and nutrition and to promote public interest in sectors of vital importance to their socio-economic and technological development' should have required the Panel to pay attention not only to 'how much the rights holder might lose' but 'how much society might gain, from a given exception. ${ }^{, 70}$ Interests of public health, those of the user of protected technologies together with the interests of the patentee are all 'legitimate interests' in the eyes of the TRIPS Agreement that warrant appropriate consideration.

From this brief analysis it is evident that the interpretation by the Panel does not reflect the above definition of a good faith interpretation. First, by ignoring these

\footnotetext{
${ }^{69}$ Howse (n 61) 496.

${ }^{70}$ Ibid
} 
provisions the Panel is failing to follow accepted interpretative practice as required by Article 3.2 of the WTO's Dispute Settlement Understanding. The 'General Rule of Interpretation' requires a holistic analysis of all the stated elements - including object and purpose. In fact, rather than look to the object and purpose for interpretative guidance, the Panel had direct recourse to the negotiating history of the TRIPS Agreement and even the Berne Convention to identify the ordinary meaning of the text. $^{71}$

Secondly, by ignoring Articles 7 and 8 in the interpretative process risks making these provisions obsolete. If they have no role to play as object and purpose then it is natural to reach the conclusion that they have no meaning within the TRIPS Agreement. ${ }^{72}$ Such an approach fails to appreciate the holistic nature of treaties and runs counter to the principle of effectiveness. As noted by Carlos Correa, 'If the Agreement itself contains a definition of its purpose, as Article 7 does, panels and the Appellate Body cannot ignore it or create their own definition in interpreting other provisions of the Agreement. ${ }^{, 73}$

Despite, 1) the Panel's confirmation that 'Both the goals and the limitations stated in Articles 7 and 8.1 must obviously be borne in mind' when giving meaning to other provisions of the TRIPS Agreement; 2) the Appellate Body's acknowledgement that these provisions 'still await appropriate interpretation'; and 3) the Ministerial Declaration on TRIPS and Public Health sanctioning their use as object and purpose,

\footnotetext{
${ }^{71}$ Canada-Pharmaceuticals (n 6) [7.29]. Frankel (n 61) 398; Howse (n 61) 496. Although consulting preparatory documentation is authorized under the Vienna Convention rules it is only to occur following the application of the rule in Article 31 and then only to confirm the interpretation or to add further guidance (art 32 Vienna Convention).

${ }^{72}$ Frankel (n 61) 397.

${ }^{73}$ Correa (n 3) 93.
} 
there has been no subsequent use of Articles 7 and 8 in this context. ${ }^{74}$ This may be because the authority of the Ministerial Declaration is seen only to exist in relation to public health and this issue has not been raised before the Panel or Appellate Body since Canada-Pharmaceuticals. ${ }^{75}$ An alternate explanation may be that the full effect of the Panel's correlation between Article 7 and the principle of good faith in $U S-s 211$ has yet to be fully appreciated, given that the Appellate Body did not directly address the issue when it reversed the Panel on many of its key findings.

However, the first real opportunity for a WTO tribunal to revisit this interpretative approach, in light of the Declaration on TRIPS and Public Health, may be about to present itself. ${ }^{76}$ Fertile ground for the application of good faith interpretation, in a public health context, can be found in the five complaints currently filed against Australia and its 2011 legislation on plain packaging for tobacco products. ${ }^{77}$ Ukraine,

\footnotetext{
${ }^{74}$ Ruse-Khan (n 22) 21-24.

${ }^{75}$ This limited role for the Ministerial declaration is not accepted by Dinwoodie and Dreyfuss, who note that 'While the Declaration was made in the context of a health crisis and precipitated an amendment to the Agreement, the provision on Article 7 was (like the rest of the Declaration) not confined to that context and was viewed as explaining-not modifying-the Agreement' Dinwoodie and Dreyfuss (n 3) 110. ${ }^{76}$ In EC - Trade Marks and Geographical Indications for Agricultural Products and Foodstuffs the Panel made a detailed analysis of Article 17, as providing for exceptions to trade mark rights, and goes some way towards analysing them in terms of a balance of competing interests. However, the Panel did not utilise articles 7 and/or 8 in this process, perhaps in light of the fact that the national measures in question did not relate to a public health matter. WTO, European Communities: Protection of Trademarks and Geographical Indications for Agricultural Products and Foodstuffs - Report of the Panel (15 March 2005) WT/DS174 \& 290/R (EC - GI [7.644] - [7.686]. For a discussion on the interpretative approach of the Panel in this case see Dinwoodie \& Dreyfuss (n 3) 82.

${ }^{77}$ WTO, Australia: Certain Measures Concerning Trade Marks and other Plain Packaging Requirements Applicable to Tobacco Products and Packaging - Request for the Establishment of a Panel by Ukraine
} 
Honduras, Dominican Republic, Cuba and Indonesia each claim that Australian law, requiring all tobacco products to be sold in plain packaging, is in violation of several trade mark obligations in the TRIPS Agreement. ${ }^{78}$ In particular, these countries complain that Australian law renders ineffective the trade mark rights of individuals by creating an unjustifiable encumbrance on the use of the marks, which thereby discriminates against tobacco related trade marks and the owners' legitimate rights ${ }^{79}$.

However, like the patent section, the trade mark section of the TRIPS Agreement contains a provision which authorises legitimate exceptions to the granted rights. Article 17 closely resembles the wording of Article 30 and requires that any exception must be 'limited' and 'take account of the legitimate interests of the owner of the trademark and of third parties'. In addition, Article 20 prevents special requirements being placed on the use of a mark only to the extent that they are considered 'unjustifiabl[e] encumb[rances]'. As argued above, in interpreting the scope of any TRIPS provision, the WTO tribunal is under a good faith obligation to have full regard to the object and purpose of the Agreement as contained within Articles 7 and 8.

(17 August 2012) WT/DS434/11; Request for the Establishment of a Panel by Honduras (17 October 2012) WT/DS435/16; Request for Consultations by the Dominican Republic (18 July 2012) WT/DS441/1; Request for Consultations by Cuba (3 May 2013) WT/DS458/1; Request for Consultations by Indonesia (20 September 2013) WT/DS467/1 (current status of disputes as of 14 December 2013).

${ }^{78}$ Tobacco Plain Packaging Act 2011. Section 20(1) states that 'no trade mark may appear anywhere on the retail packaging of tobacco products, other than [the brand, business or company name (display of brand, business or company name regulated by the Act)].

${ }^{79}$ This is argued to be contrary to articles $15.1,15.4,16.1,16.3$ and 20 of the TRIPS Agreement 
Given the public health nature of this dispute, the TRIPS Agreement should be construed 'in a manner that is conducive to social and economic welfare' (Article 7), and to acknowledge that 'Members may adopt measure necessary to protect public health... provided such measures are consistent with the provisions of this Agreement' (Article 8). ${ }^{80}$ Here the 'consistency' requirement places what appears to be a significant constraint on national autonomy. Yet, if we analyse the consistency requirement of Article 8 in light of the conditions placed upon the grant of the limitations and exceptions to the exclusive rights, we can see that 'inconsistency' may, in fact, be hard to establish given the ambiguous nature of these provisions. For example, Article 17 requires that any exception to trade marks rights must 'take account of the legitimate interests of the owners of the trade mark and of third parties.' Here the interests of others are a key factor in determining the legitimacy of an exception. However, there is no explicit mention of nature and extent of the relevant third party interests. Yet, in light of the terms of Articles 7 and 8, it would seem illogical to suppose that the consistency requirement should prevent Member States from taking action to protect public health. ${ }^{81}$

The consistency requirement is there not because negotiators intended IP rights to trump other national policies, but as an indicator that there is sufficient room within the other provisions of the TRIPS Agreement, including the exceptions, to accommodate those policies. In which case, the consistency requirement, if interpreted in light of the object and purpose of the Agreement, skews in favour of the wider public interest when

\footnotetext{
${ }^{80}$ Section 3 of Australia's Tobacco Plain Packaging Act, expressly states that the legislation's overarching objective is to improve public health and thereby give effect to international obligations arising under the Convention on Tobacco Control.

${ }^{81}$ Correa (n 3) 108.
} 
it comes into conflict with intellectual property rights. Public Health is a legitimate public policy objective that should not be subordinated to private rights of intellectual property owners. If an exception is required, then a good faith interpretation, in accordance with Articles 7 and 8, should seek to encompass a broader range of third party interests and not focus entirely upon the impact of a measure on the IP rights of individuals, as was the case in Canada-Pharmaceuticals.

This dispute presents many complex issues concerning the scope of trade mark rights, which it is impossible to consider in detail here. However, the nature of the complaint, in pitting intellectual property rights against national public health objectives, provides the perfect opportunity for the Panel to consider the relevance of the object and purpose of the Agreement as expressed in Articles 7 and 8. The public health context also underscores the significance of the Ministerial Declaration on TRIPS and Public Health (which sanctioned the use of Articles 7 and 8 as object and purpose) and will allow the Panel to determine its relevance for the interpretative process. Much is riding on the outcome of this dispute, with many WTO Members, including New Zealand, ${ }^{82}$ the United Kingdom ${ }^{83}$, and the European Union, ${ }^{84}$ debating the possibility of following Australia's lead and introducing plain packaging for all tobacco related products. Therefore, it is important that the Panel engage fully with the object and purpose of the TRIPS Agreement to ensure that it provides a good faith interpretation of the text.

\footnotetext{
${ }^{82}$ Tariana Turia (Associate Minister for Health), 'Government moves Forward with Plain Packaging of Tobacco Products' (19 February 2013) http://www.beehive.govt.nz/release/government-moves-forwardplain-packaging-tobacco-products accessed 14 December 2013.

${ }^{83}$ Denis Campbell and Patrick Wintour, 'Cigarettes could get Plain Packaging by 2015 after a Government U-Turn' The Guardian (London, 28 November 2013) http://www.theguardian.com/society/2013/nov/27/review-plain-packaging-cigarettes-2015 accessed 14 December 2013.

${ }^{84}$ Claire Davenport, 'European Parliament Votes to Weaken EU's Anti-smoking Plans' Reuters (8 October 2013) http://uk.reuters.com/article/2013/10/08/uk-eu-tobacco-idUKBRE9970FG20131008 accessed 14 December 2013.
} 
Article 7 seeks to deliver 'a balance of rights and obligations' for its Members. Whilst the obligation to provide adequate protection for intellectual property rights so as to 'reduce distortions and impediments to trade' is fundamental to the TRIPS Agreement, it has to be balanced against Members' right to take measures to protect other important public interests, such as public health. These competing objectives and purposes are actually preserved within Articles 7 and 8 themselves and good faith demands that they receive appropriate attention, at the very least, through the application of object and purpose and the principle of effectiveness as enshrined within Article 31.1 of the Vienna Convention.

Having analysed the regulatory and interpretative expressions of good faith enshrined within the Vienna Convention and accepted by the WTO as authoritative WTO jurisprudence, it is necessary to look beyond the codification of the good faith principle and ask to what extent WTO jurisprudence accepts good faith as a 'general principle' of WTO law? - The wider the impact of the good faith principle the greater the relevance of Article 7. However, in its role as a general principle of law good faith becomes a rather nebulous concept with ill-defined boundaries. ${ }^{85}$ This is partly due to disagreement as to which principles are considered corollaries of good faith ${ }^{86}$ and partly due to its link with rather vague concepts such as fairness, honesty, reasonableness and

\footnotetext{
${ }^{85}$ Good faith is described as one of the broadest concepts of international law. Zeitler (n 18) 721-722.

${ }^{86}$ For example, Kolb identifies only three main aspects of the principle of good faith within international law generally. Yet Lennard identifies nine within the WTO jurisprudence itself, beyond those emanating from the interpretative obligation in Article 31.1 of the Vienna Convention. Kolb (n 9) 17; Michael Lennard, 'Navigating by the Stars: Interpreting the WTO Agreement', (2002) 5 J. Int'l Econ. L. 17, 55 -
} 76. 
morality. ${ }^{87}$ Defining the scope of the general principle of good faith is therefore beyond the scope of this work. Hence the following will not argue that Article 7, as a form of the good faith principle, is a source of all such emanations of the principle into the TRIPS Agreement. However, it will focus on accepted good faith jurisprudence of the WTO and seek to define its relevance for Article 7. This will include an analysis of the doctrine of abus de droit and the principle of legitimate expectations.

\section{Abus de Droit}

As recognised by the Appellate Body in US- Shrimp and acknowledged by the Panel in $U S-s 211$, the doctrine of 'abuse of rights' is a tangible application of the general principle of good faith ${ }^{88}$ that 'prevents a Party to an agreement from exercising its rights in a way that is unreasonable in light of the spirit of the agreement'. ${ }^{89}$ Cheng associates the abuse of rights doctrine with the malicious exercise of rights where the purpose is to injury others; the evasion of treaty obligations by feigning the exercise of a right; exercising a national right in a way that conflicts with an international treaty obligation to another state; and discretionary rights exercised unreasonably, dishonestly and without due regard for the interests of others. ${ }^{90}$

\footnotetext{
${ }^{87}$ O'Connor (n 33) 124; Thomas Cottier and Krista N Schefer, 'Good Faith and the Protection of Legitimate Expectations in the WTO' in Marco Bronckers and Reinhard Quick (eds) New Directions in International Economic Law: Essays in Honour of John H Jackson (Kluwer Law International 2000) 50. ${ }^{88}$ US - Shrimp (n 12) [158]; US - s211 (n 8) [8.57]; Bin Cheng, General Principles of Law as Applied by International Courts and Tribunals (Grotius, 1987) 121.

${ }^{89}$ Cottier and Schefer (n 86) 51.

${ }^{90}$ Cheng (n 87) 121-136.
} 
The Appellate Body decision in US - Shrimp has been described as 'a landmark', being the first express recognition of the doctrine of abus de droit in WTO law. ${ }^{91}$ By connecting the doctrine of abus de droit to the substantive exceptions rule contained in Article XX of the GATT, the Appellate Body has utilised the doctrine to control the exercise of rights by a Member State. In this case, the state's permissible action in exercising an exception was claimed to encroach upon the trading rights of other Members enshrined within the GATT. Consequently, all Member States must execute such rights 'bona fide [s], that is to say reasonably. ${ }^{92}$ As noted by the Appellate Body: -

To permit one Member to abuse or misuse its right to invoke an exception would be effectively to allow that Member to degrade its own treaty obligations as well as to devalue the treaty rights of other Members. If the abuse or misuse is sufficiently grave or extensive, the Member, in effect, reduces its treaty obligation to a merely facultative one and dissolves its juridical character, and, in so doing, negates altogether the treaty rights of other Members. ${ }^{93}$

Here the doctrine of abus de droit takes on a substantive function that seeks to find a balance between the effective application of the treaty and the right to exercise certain exceptions to the rights and obligations arising under the treaty. Within the judgement it is possible to draw upon dicta that support the use of the doctrine of abus de droit as

\footnotetext{
${ }^{91}$ Cottier and Schefer (n 86) 65.

${ }^{92}$ US - Shrimp (n 12) [158], quoting Cheng (n 87) 125.

${ }^{93}$ Ibid, [156].
} 
an autonomous source of legal obligations, albeit implicitly included within the chapeau of Article XX of the GATT. For example, 'An abusive exercise by a Member of its own treaty right thus results in a breach of the treaty rights of the other Members and, as well, a violation of the treaty obligation of the Member so acting., 94

However, the Appellate Body appears to stop short of acknowledging an independent legal role for abus de droit by immediately stating that, 'Having said this, our task here is to interpret the language of the chapeau, seeking additional interpretative guidance, as appropriate, from the general principles of international law. ${ }^{95}$ By seemingly stepping back from accepting the substantive relevance of the doctrine the Appellate Body may have instead given the first judicial recognition to the principle of good faith treaty interpretation, thereby incorporating good faith interpretative maxims independent of the holistic approach espoused by Article 31 of the Vienna Convention. ${ }^{96}$ Nevertheless, whether as a substantive rule or an interpretative tool 'the approaches may, in the end, be difficult to distinguish in practical terms. ${ }^{, 97}$ Either way the actions of the parties to the dispute are measured against the principle of good faith as expressed within the doctrine of abus de droit.

In US -Shrimp the Appellate Body makes significant inroads into incorporating the general principle of good faith into the legal framework of the GATT, even if the actual nature of its application is somewhat obscure. ${ }^{98}$ By associating the same principle and

\footnotetext{
${ }^{94}$ Ibid, [158].

${ }^{95}$ Ibid. Mitchell (n 13) 370.

${ }^{96}$ Cottier and Schefer (n 86) 65.

97 Ibid.

${ }^{98}$ Zeitler critiques the DSB's references to broad concepts, such as good faith, that leave Member States unclear and concerned about the implications. Zeitler (n 18) 755-756.
} 
reasoning to Article 7 of the TRIPS Agreement the significance is replicated within the confines of the WTO's intellectual property law. It is possible to conclude that the Panel intended Article 7 (as 'a form of the good faith principle') to act as either a substantive or interpretative constraint upon Member States, preventing any abuse of rights expressly when 'implement[ing]' their obligations under the TRIPS Agreement. This is a significant development that does not easily succumb to concerns regarding judicial activism. As noted by Cottier and Schefer, abus de droit is a judicial construct not a doctrine that could readily be considered within the legislative process. Abuse of rights requires a fact specific investigation that can only be carried out by the DSB. ${ }^{99}$ In this regard it may be said that the judicial organ of the WTO has not exceeded its mandate by establishing the relevance of abus de droit within the WTO and, in particular, Article 7.

Following the lead established by the Appellate Body in US - Shrimp, Article 7 appears to take on a specific role in the regulation of the TRIPS Agreement. It invokes the abuse of rights doctrine to effectuate a balance between the obligations arising under the Agreement with the right to invoke exceptions to those obligations. As noted by the Appellate Body in US - Shrimp: -

[W] consider that [the chapeau of Article XX] embodies the recognition on the part of WTO Members of the need to maintain a balance of rights and obligations between the right of a Member to invoke one or another of the

\footnotetext{
${ }^{99}$ Cottier and Schefer (n 86) 52. As noted by Barbosa et al, 'principles [unlike rules] are not applied in the abstract, but rather to the facts in a specific case, upon chosen value grounds'. Barbosa, Chon and Moncayo von Hase (n 67) 108.
} 
exceptions of Article XX...on the one hand, and the substantive rights of the other Members under the GATT 1994, on the other hand. ${ }^{100}$

Article 7, as a form of the good faith principle, expressly requires that same balancing of rights and obligations. ${ }^{101}$

However, it must be acknowledged that the Panel in US-s211 and the Appellate Body in US-Shrimp utilise the principle of abus de droit as a safeguard against arbitrary limitations placed on the substantive rights. Yet, it should not be supposed that its only application is to constrain the use of limitations and exceptions to the granted rights. As stated above, the abuse of rights doctrine ensures that a balance of rights and obligations is maintained. Therefore, not only can the abuse of rights doctrine, as articulated within Article 7, be used as a 'sword' to review measures that place limitations on the granted rights, it can also function as a 'shield' to defend against the use of such measures. For example, the abuse of rights doctrine could be advanced as a defence when action taken to limit the scope of patent rights in pursuit of a public health objective is challenged before the WTO Dispute Settlement Body. Given that Article 8.1 and the Doha Declaration on TRIPS and Public Health now allow for measures to be taken to protect public health, a defendant could rely on Article 7 to argue that the challenger is abusing their right to bring a WTO violation complaint. This

\footnotetext{
${ }^{100}$ US - Shrimp (n 12) [156].

${ }^{101} U S-s 211(\mathrm{n} 8)$ [8.57]
} 
would be so unless the challenging Member is able to clearly establish that the measure in question was inconsistent with other provisions of the TRIPS Agreement. ${ }^{102}$

Consequently, the application of abus de droit within the TRIPS Agreement can be seen to encompass the doctrine of abuse of process. This doctrine requires that a tribunal should refuse to exercise its jurisdiction where the litigation is brought in circumstances that are 'manipulative and abusive. ${ }^{103}$ These include situations 'where the purpose of the litigation is to harass the defendant, or the claim is frivolous or manifestly groundless, or the claim is one which could and should have been raised in earlier proceedings. ${ }^{, 104}$

In has been argued that Article 8 of the TRIPS Agreement shifts the burden of proving inconsistency with the TRIPS Agreement to the challenging party. ${ }^{105}$ Accordingly, the challenger must provide sufficient evidence that the public health

\footnotetext{
${ }^{102}$ Article 8 requires that any measures taken in pursuit of the objectives stated in Article 8 must be consistent with the rest of the Agreement.

${ }^{103}$ WTO, EC: Anti-Dumping Duties on Imports of Cotton-Type Bed Linen from India-Recourse to
} Article 21.5 of the DSU by India - Report of the Panel (29 November 2002) WT/DS141/RW [6.43]. The Panel, in this case, expressed concern about the possibility of introducing abuse litigations practices if they allowed Article 21.5 of the DSU to be utilised to raise claims that had not be heard, or were dismissed, in the original proceedings.

${ }^{104}$ Vaughan Lowe, 'Overlapping Jurisdiction in International Tribunals' (1999) 20 Aust. YBIL 191, 202. As noted by Joost Pauwelyn, the doctrine of abuse of process is recognised, to some extent, in Article 3.7 of the DSU which states that, 'Before bringing a case, a Member shall exercise its judgement as to whether action under these procedures would be fruitful.' However, the argument for abuse of process being made here incorporates yet extends beyond the subjective assessment of the fruitful nature of the action. Joost Pauwelyn, Conflict of Norms in Public International Law: How WTO Law Relates to Other Rules of International Law (CUP, 2003) 116.

${ }^{105}$ UNCTAD-ICTSD, Resource Book on TRIPS and Development (CUP 2005) 126 
measure in question is inconsistent with the TRIPS Agreement, or risk having the claim thrown out as 'frivolous or manifestly groundless' and thus an abuse of process.

As noted above, inconsistency may be harder to establish than may first appear. ${ }^{106}$ If interpreted in light of the object and purpose of the Agreement it could reasonably be argued that 'Articles 7 and 8 impose on Members the correlative obligation to refrain from questioning of sanctioning those acts of other Members that make use of the freedom conferred to them by the said provisions. ${ }^{, 107}$ Nevertheless, claims of 'frivolous or manifestly groundless' litigation must be grounded in something more definite than exception provisions with uncertain scope. To illustrate this point it is possible to turn, once again, to the upcoming WTO litigation surrounding Australia's law on plain packaging for tobacco products in order to observe how the above approach may be applied.

Broadly speaking, academic commentary on the legitimacy of Australia's law has produced two, somewhat distinct, lines of argument. The first body of opinion debates the scope of both Article 17 and 20 of the TRIPS Agreement to determine whether the national measures in question can amount to a 'limited' exception or be a 'justifiable encumbrance' upon the owner's rights. ${ }^{108}$ This approach accepts that the national

\footnotetext{
${ }^{106}$ See page 29.

${ }^{107}$ Andrés Moncayo von Hase, 'The Application and Interpretation of the Agreement on Trade-Related Aspects of Intellectual Property Rights' in Carlos M Correa and Abdulqawi A Yusuf, Intellectual Property and International Trade: The TRIPS Agreement (Kluwer Law International 2008) 118.

${ }^{108}$ For example, Alberto Alemanno and Enrico Bonadio, 'Do you mind My Smoking? Plain Packaging of Cigarettes Under the TRIPS Agreement' (2011) 10 J. Marshall Rev. Intell. Prop. L. 450; Daniel Gervais, 'Analysis of the Compatibility of Certain Tobacco Product Packaging Rules with the TRIPS Agreement and the Paris Convention' (2010) (Report prepared for Japan Tobacco International) http://www.jti.com/how-we-do-business/key-regulatory-submissions/ accessed 15 December 2013;
} 
measure is doubtless restricting the rights granted under the TRIPS Agreement, yet it may be justified in light of these limitations and exceptions that have been placed on the trade mark rights. Viewed from this perspective, a challenge to Australia's tobacco legislation is not likely to be perceived as an abuse of WTO rights/process, even though Article 8 prima facie provides support for the introduction of such public health measures. As noted, the nature of these exception and limitation provisions are just too uncertain for Australia to convincingly argue that it has no case to answer.

The second approach asserts that plain packaging does not even fall within the scope of these provisions as intellectual property rights are 'negative' not 'positive' in nature, i.e. a negative right to prevent others from utilising the mark, rather than a positive right to exploit it. ${ }^{109}$ Absent any express statement to the contrary, a right to use a trade mark cannot be implied into the Agreement. Consequently, as the Australian law only restricts use of the mark for public health purposes and does not hinder the owner's ability to prevent others from utilising the mark, it does not fall within the scope of the TRIPS Agreement whatsoever and thus does not need to be justified via an exception to the granted rights. ${ }^{110}$ This approach provides much firmer ground upon

Lalive, 'Why Plain Packaging is in violation of WTO Members' International Obligations under TRIPS and the Paris Convention' (2009) (Report prepared for Philip Morris International Management SA). ${ }^{109}$ For example, Mark Davison, 'The Legitimacy of Plain Packaging Under International Intellectual Property Law: Why there is no Right to Use a Trademark under Either the Paris Convention or the TRIPS Agreement' in A Mitchell, T Voon and J Liberman (eds) Public Health and Plain Packaging of Cigarettes: Legal Issues (Edward Elgar, 2012).

${ }^{110}$ It must be stressed that each side of the argument is infinitely more complex and nuanced than that presented here. For a detail analysis of both sides of the debate see Susy Frankel and Daniel Gervais, 'Plain Packaging and the Interpretation of the TRIPS Agreement' (2013) Vand. J. Transnat'l. L. Forthcoming. http://papers.ssrn.com/sol3/papers.cfm?abstract_id=2234580 accessed 15 December 2013. 
which to argue that the challenging States are abusing their right to bring a violation complaint. It would be feasible for Australia to argue that the challenging States' complaint presents a fundamental misunderstanding of the nature of the trade mark obligations under the TRIPS Agreement and Paris Convention. In so doing, the basis of their complaint has no foundation in the Agreement and is thus frivolous or manifestly groundless, thereby an abuse of rights and dispute settlement process.

While it must be accepted that the divergence of opinion on the nature of the trade mark obligations within TRIPS weakens the strength of this argument in this particular case, it is clear that the principle of abus de droit as articulated in Article 7 of the TRIPS Agreement provides a viable basis for such a claim. Peter Yu observes that Article 7, per se, could already function as a 'shield' in actions brought to challenge State autonomy when it comes to issues of public health and the conflict with intellectual property rights. ${ }^{111}$ However, as an expression of the doctrine of abus de droit Article 7 articulates an established legal principle, in the context of the TRIPS Agreement that the WTO Dispute Settlement Body would appear willing to apply.

\section{Legitimate Expectations}

As noted, the WTO has accepted the interpretative rule espoused by the Vienna Convention as representative of 'customary rules of interpretation of public international law'. Yet, whilst this approach to treaty interpretation is predicated upon the need for certainty and predictability which is seen to flow from identifying the intentions of the parties as expressed in the agreement, the way it has been applied by

\footnotetext{
${ }^{111} \mathrm{Yu}(\mathrm{n} 3)$ 1025-1039.
} 
the WTO has been criticised for too rigid a reliance upon Article 31. This ultimately restricts recourse to other rules of treaty interpretation that might guide the interpretative processes and broaden the scope and nature of the WTO's analysis. ${ }^{112}$ Attempts were made in the first TRIPS-related case to introduce interpretative canons derived not directly from the constituent elements of Article 31 of the Vienna Convention, but from the general principle of 'good faith interpretation' itself. ${ }^{113}$ As stated by the Panel in India - Patent Protection for Pharmaceutical and Agricultural Chemical Products, 'In our view, good faith interpretation requires the protection of legitimate expectations. ${ }^{114}$ Whilst the Panel did make reference to Article 31.1 it is clear that its analysis did not adopt the holistic approach subsequently advocated by the Appellate body in EC-Frozen Boneless Chicken Cuts, ${ }^{115}$ but focussed upon the requirement of good faith.

According to Cottier and Schefer: -

The principle [of the protection of legitimate expectations] commands that if a Party had reason to believe, based on the actions or words of another Party, that a situation or occurrence would or would not change in a particular manner, the other Party may not change the situation in that manner. ${ }^{116}$

\footnotetext{
${ }^{112}$ Asif H Qureshi, Interpreting WTO Agreements: Problems and Perspectives (CUP 2006) 8.

113 Panizzon (n 11) 227-231.

${ }^{114}$ WTO, India: Patent Protection of Pharmaceutical and Agricultural Chemical Products (5 September 1997) WT/DS50/R [7.18] (India - Patent Protection).

${ }^{115}$ EC-Frozen Chicken (n 48) [176].

${ }^{116}$ Cottier and Schefer (n 86) 53.
} 
The Panel in India - Patents found that 'the protection of legitimate expectations is central to creating security and predictability in the multilateral trading system' and thus 'when interpreting the text of the TRIPS Agreement, the legitimate expectations of WTO Members concerning the TRIPS Agreement must be taken into account. ${ }^{117}$ In examining India's 'mailbox' system for compliance with Articles 63, 70.8, and 70.9 of the TRIPS Agreement, the Panel concluded that the system frustrated the legitimate expectation of WTO Members by failing to protect equal conditions of competition between home nationals and nationals from other Member States. ${ }^{118}$ In addition, the system did not offer security and predictability for individuals seeking to preserve the novelty and priority of their inventions. ${ }^{119}$

The connection between good faith interpretation and the protection of legitimate expectations would have been a significant development in the jurisprudence of the WTO. It would have indicated a move away from regarding the text of the treaty as the definitive record of the intentions and expectations of the parties, to one where the judicial enquiry into general principles of law help to shape the content of the WTO Agreement. ${ }^{120}$

This was a step too far for the Appellate Body who was quick to rein in the Panel. The Appellate Body decision plainly indicates that the principle of the protection of

\footnotetext{
${ }^{117}$ India-Patent Protection (n 113) [7.21] \& [7.22].

${ }^{118}$ Ibid, [7.53].

${ }^{119}$ Ibid, [7.41].

${ }^{120}$ For a critique of the Panel's decision see Jacques Werner, 'The TRIPS Agreement under the Scrutiny of the WTO Dispute Settlement System: The Case of Patent Protection for Pharmaceutical and Agricultural Chemical Products in India' (1998) 1 J. World Intell. Prop. 309.
} 
legitimate expectations, as derived from the requirement to interpret a treaty in good faith, in not an aspect of WTO interpretative practice, at least as far as violation complaints are concerned. According to the Appellate Body the Panel had erred in adopting legitimate expectations as an interpretative benchmark. ${ }^{121}$ This approach was incorrect for two reasons. First, it had introduced principles developed to deal with nonviolation complaints ${ }^{122}$ into a dispute which actually related to a violation complaint and into a treaty that expressly excluded the application of such complaints. ${ }^{123}$ Secondly, with regard to the Panel's finding that the principle of good faith interpretation provided the basis for the protection of legitimate expectations, the Appellate Body dismissed such an approach and confirmed that the legitimate expectations of the Members are to stem from the language of the treaty itself. ${ }^{124}$ Accordingly, the Panel had misapplied Article 31 of the Vienna Convention which 'neither require nor condone the imputation into a treaty of words that are not there or the importation into a treaty of concepts that were not intended. ${ }^{125}$ Moreover, Articles

\footnotetext{
${ }^{121}$ WTO, India: Patent Protection of Pharmaceutical and Agricultural Chemical Products (19 December 1997) WT/DS50/AB/R, [36]-[42] (India - Patent Protection).

${ }^{122}$ Under Article XXIII(b) of the GATT 1994 a non-violation complaints can be initiated where there is no breach of the provisions of the covered agreement, but where the negotiated balance is upset by another Member's actions.

${ }^{123}$ India - Patent Protection (n 120) [42]. The TRIPS Agreement, article 64.2 prohibits the application of non-violation complaints to the TRIPS Agreement for five years from the date of entry of the Agreement. Despite extensive debate on the issue within the Council for TRIPS, non-violation complaints are still not a valid form of action for the TRIPS Agreement.

${ }^{124}$ Ibid, [45].

125 Ibid.
} 
3.2 and 19.2 of the DSU require that both the Panel and the Appellate Body 'must not add to or diminish rights and obligations provided in the WTO Agreement., ${ }^{126}$

Whilst the Appellate Body appeared to curtail the ability of the good faith principle to expand the range of interpretative maxims available to the WTO, this has to be considered in light of the Appellate Body decision in US - Shrimp, discussed above. Here the Appellate Body suggests that good faith interpretation can bring about the assimilation of important good faith maxims into the WTO legal system, such as abus de droit. However, in the Shrimp case good faith was linked to a specific GATT provision; in India - Patents there is no such connection. Yet, more recent Appellate Body jurisprudence appears to accept a more expansive role in that 'The principle of good faith may therefore be said to inform a treaty interpreter's task. ${ }^{127}$ Whether such acknowledgement signifies a discrete role for interpretative good faith or whether it merely reasserts the central role that good faith plays within Article 31.1 of the Vienna Convention is not evident from the Appellate Body's reasoning. Either way the value of the principle of good faith is underscored for the interpretative process.

Notwithstanding the rejection by the Appellate Body of the principle of good faith interpretation as an autonomous source of interpretative principles, it did not dismiss entirely the relevance of legitimate expectations for WTO jurisprudence, it only limited its role to that of non-violation complaints. However, as mentioned above, the TRIPS Agreement has yet to recognise such complaints. There is much debate as to whether it would be a suitable Agreement for such disputes, due to, inter alia, its structural nature

\footnotetext{
${ }^{126}$ Ibid, [46]-[47].

${ }^{127}$ US - Offset Act (n 42) [296].
} 
as a minimum standards agreement, ${ }^{128}$ or because such disputes would act as a further restraint on the ability of individual nations to tailor their TRIPS obligations to reflect their own national interests. ${ }^{129}$ Yet, in the context of non-violation complaints the principle of good faith 'challenges the concept of the sufficiency of the text of the agreement, because it implies that duties not explicitly assumed under the agreement may nonetheless be imposed if required by good faith. ${ }^{130}$ Here the role of good faith and its corollary - legitimate expectations - play a vital role in maintaining expectations as to conditions of market access and also reciprocal trade benefits which could be imported into the TRIPS Agreement should non-violation disputes be authorised.

By connecting Article 7 with the principle of good faith the Appellate Body has provided an adequate basis for the incorporation of corollaries of the wider good faith principle should non-violation complaints become approved. That being said there is some uncertainty as to the legitimacy of this approach for violation complaints. In India - Patents the Appellate Body dismissed the relevance of legitimate expectations derived from the application of 'good faith interpretation.' Yet, in US -Shrimp it may be concluded that where the principle of good faith can be linked to a specific provision 'good faith interpretation' may authorise the incorporation of good faith maxims - in that case abus de droit. Whilst this approach maintains a connection with the authoritative text, it only does so by implication. The actual source of the rule is not the covered text but rather a general principle of law, albeit one that the WTO Dispute Settlement Body deems is implied in the text.

\footnotetext{
${ }^{128}$ Susy Frankel, 'Challenging TRIPS-Plus Agreements: The Potential Utility of Non-Violation Disputes' (2009) 12 J. Int'l Econ. L. 1023, 1045.

${ }^{129}$ Gail E Evans, ‘A Preliminary Excursion into TRIPS and Non-Violation Complaints’ (2000) 3 J. World Intell. Prop. 867, 882-886; Frankel (n 127) 1046.

${ }^{130}$ Ibid, 881.
} 


\section{WHAT ARE THE IMPLICATIONS FOR THE TRIPS AGREEMENT AND ARTICLE 7?}

In US-s211 the Panel acknowledged that the phrase 'the protection and enforcement of intellectual property rights should contribute...to a balance of rights and obligations' included in Article 7 of the TRIPS Agreement, was an expression of the good faith principle. ${ }^{131}$ The potential implications of this decision are extremely important for the TRIPS Agreement.

As we have seen, this decision by the Panel immediately introduces legal concepts into the TRIPS Agreement that are not explicit within the text. The Panel itself expressly refers to abus de droit and by implication the principle of pacta sunt servanda. This alone would be pioneering. Yet the natural correlation between the obligation to perform a treaty in good faith - pacta sunt servanda - and the obligation to interpret a treaty in good faith automatically brings within the scope of Article 7 other corollaries of the good faith principle, such as the principle of effectiveness and the protection of legitimate expectations. By connecting Article 7 with the principle of good faith the Panel incorporates rules derived from general principles of law, whilst at the same time maintaining the connection with the negotiated text of the TRIPS Agreement. This provides WTO tribunals with a degree of interpretative flexibility without overtly exposing themselves to criticism from Member States for appearing to 'add to or diminish the rights and obligations provided in the covered agreements,' contrary to Article 3.2 of the DSU. Such an approach allows the principle of good faith

${ }^{131} U S-s 211$ (n 8) [8.57]. The Panel included Articles 1.1, 3 and 4 as additional safeguards against the potential abuse by arbitrary national legislation. 
to act as a complementary rule to the covered text, whilst at the same time providing the opportunity for the WTO Dispute Settlement Body to engage with the principle and shape its form for the TRIPS context.

Good faith within the WTO has yet to become an autonomous source of law and thus Article 7 in demanding 'a balance of rights and obligations' could never alone form the basis of a WTO dispute. Yet it could bolster the argument where a Member is accused of failing to implement correctly other provisions of the Agreement. The Panel in $U S-s 211$ implies that national intellectual property legislation, in this case laws on trade mark ownership, could be subject to a review in accordance with the principle of good faith and especially that of abus de droit. It places a good faith obligation on Member States when implementing the TRIPS Agreement and thus renders Article 7 the source of a substantive, although not independent, norm. Accordingly, Article 7, as a vessel for good faith obligations, has the potential to form part of a claim before the WTO Dispute Settlement Body where rights or obligations have been implemented in a manner inconsistent with the good faith principle. ${ }^{132}$

This substantive role for Article 7 is potentially much wider than that of the chapeau in Article XX of the GATT. The chapeau, as an expression of the good faith principle, only has substantive relevance when considering the general exceptions to the GATT trading rules within Article XX. In contrast, Article 7 and its requirement of 'a balance of rights and obligations' forms part of the 'General Provisions' of the TRIPS Agreement and has potential application for the whole Agreement. Whilst the balance

\footnotetext{
${ }^{132}$ As noted by Cottier and Schefer in response to the Appellate Body's decision in US - Shrimp, by linking the chapeau in Article XX of the GATT to the principle of good faith and abuse of rights the Appellate Body seems to apply the doctrine 'as a matter of substantive law of the chapeau of Article XX GATT, expounding the essence and specific function of this elusive provision.' Cottier and Schefer (n
} 86) 65. 
of intellectual property rights protection with the permitted exceptions will clearly fall within the scope of Article 7, there are other aspects of the TRIPS Agreement that also necessitate a good faith balancing of rights and obligations. These include, for example, Article 1.1 which gives members freedom to determine the appropriate method of implementing the provision of the Agreement; Article 31 on compulsory licensing of patent rights; and Article 41.2 which requires that procedures concerning enforcement shall be fair and equitable.

Although these factors point towards an enhanced substantive role for Article 7 some possible constraints on the function of Article 7 must be highlighted. First, as noted in the quotation above, the Appellate Body in US- Shrimp utilises the principle of abus de droit to place a check upon the use of exceptions to non-discriminatory trade rules contained within Article XX of the GATT. Here the main priority is to maintain as far as possible the legal force of the substantive provisions of the GATT that prioritise liberal trade. ${ }^{133}$ Nevertheless the Appellate Body 'engages in balancing tests ${ }^{134}$ by discussing the need for: -

[L]ocating and marking out a line of equilibrium between the right of a Member to invoke an exception under Article XX and the rights of the other Members under varying substantive provisions (e.g., Article XI) of the GATT 1994, so that neither of the competing rights will cancel out the other

\footnotetext{
${ }^{133}$ US - Shrimp (n 12) [156]; Panizzon (n 11) $92 \& 95$.

${ }^{134}$ Panizzon (n 11) 92
} 
and thereby distort and nullify or impair the balance of rights and obligations constructed by the Members themselves in that Agreement. ${ }^{135}$

This has led Panizzon to hypothesise that 'it is possible that the AB has wanted to soften the harshness and unilateral emphasis on free trade with abus de droit in the context of an exception from trade liberalisation rules'. As a tool for invoking the good faith principle and abus de droit and creating a 'balance of rights and obligations', Article 7 has a role to play in finding the appropriate line of equilibrium, albeit possibly prejudiced towards prioritising liberal trade. It must be emphasised that the balance envisaged by Article 7, in this context, is limited to reconciling the competing rights and obligations specifically arising for Member States under the TRIPS Agreement, i.e. treaty obligations versus treaty exceptions/limitations/flexibilities, and not to invoking a broader range of interests from beyond the WTO texts. However, these wider interests can find a voice within the provisions of the Agreement, for example through the limitations and exceptions to intellectual property rights provided for in Articles 13, 17, 30 and 31. In functioning to ensure that these exceptions are implemented by Members States in good faith, Article 7 can help to legitimise the integration of a broader range of economic and social interests within the context of the TRIPS Agreement. The obligation to interpret a treaty in good faith will also facilitate the incorporation of a wider range of interests. A holistic analysis of all the elements of Article 31.1 of the Vienna Convention together with all the elements of the TRIPS Agreement will ensure that the object and purpose of TRIPS as enshrined within Articles 7 and 8 of the Agreement become guides to the interpretation of other provisions of the treaty. Health,

${ }^{135}$ US - Shrimp (n 12) [159] 
nutrition, socio-economic development and technology transfer, to name but a few, are all expressed within these provisions and become legitimate interests when analysing the scope of other provisions of the Agreement.

Secondly, on appeal, the Appellate Body in $U S-s 211$ did not equate the principle of good faith specifically with Article 7 of the TRIPS Agreement and the 'balance of rights and obligations' as expressed. Yet it did indicate that the requirement to implement rights and obligations in good faith applies to the WTO Agreement as a whole. The Appellate Body stated that 'it cannot be assumed that the WTO Member will fail to implement its obligations under the WTO Agreement in good faith. ${ }^{136}$ Yet, a presumption in favour of a good faith implementation does not arise without there first being a positive duty to implement in good faith. As observed by Panizzon 'the AB has introduced a self-standing obligation to implement all the WTO Agreements in good faith, based upon a Panel decision that had applied such a duty to the TRIPS Agreement only., ${ }^{137}$ Therefore, although the Appellate Body decision did not expressly reinforce the function of Article 7 of the TRIPS Agreement as an expression of the good faith principle, it did confirm that a general obligation existed to implement all the WTO Agreements in good faith.

Following the recognition by the Panel that Article 7 is a form of the good faith principle, it has been possible to identify specific understandings to attach to this good faith principle and to also determine how this principle may be applied to create an impact on the substantive scope of the TRIPS Agreement. Article 7 mandates 'a balance

\footnotetext{
${ }^{136}$ US - s211 (n 28) [259]. The Appellate Body has held that good faith on the part of the Members States is to be presumed, European Communities: Trade Description of Sardines - Report of the Appellate Body (26 September 2002) WT/DS231/AB/R [278].

${ }^{137}$ Panizzon (n 11) 87.
} 
of rights and obligations' which imparts a good faith obligation upon those implementing the TRIPS Agreement and those interpreting it. As demonstrated in relation to the upcoming WTO hearing against Australia, by reversing the interpretative approach of the Panel in Canada-Pharmaceuticals and accepting the application of the principle of abus de droit, Article 7 of the TRIPS Agreement can influence the outcome of this high profile dispute and define once and for all the boundary between intellectual property rights protection and the protection of public health.

\section{CONCLUSION}

In Canada-Pharmaceuticals the WTO Panel failed to provide an adequate analysis of Article 7 and disregarded its interpretative value in defining the object and purpose of the TRIPS Agreement. However, in $U S-s 211$ the Panel undoubtedly views this provision as being of far greater significance for the Agreement. In recognising that 'the protection and enforcement of intellectual property rights should contribute...to a balance of rights and obligations' is a form of the good faith principle, the Panel acknowledges a legal function for Article 7. It then goes on to identify aspects of the good faith principle that Article 7 can be seen to obligate - pacta sunt servanda and its derivative abus de droit. In analysing the nature of the good faith principle and its role within the WTO, it is possible to conclude that Article 7 will not only facilitate greater adherence to good faith implementation and interpretation as a general principle of public international law, it will also have a substantive function within the TRIPS Agreement, albeit as a subsidiary claim to a violation complaint. This role would also 
be extended to non-violation complaints should they ever become accepted within the context of the TRIPS Agreement.

The decision of the Panel not only introduces into the TRIPS Agreement legal concepts that do not find themselves expressed in the text, it also obliges 'a balancing of rights and obligations' that up to this point have been conspicuously absent from the reasoning of the WTO tribunals. This is an important decision the effects of which have yet to fully materialise. However, the groundwork has been set for Article 7 and the principle of good faith to have a far greater role within the jurisprudence of WTO TRIPS Agreement in the very near future. The complaints against Australia and its tobacco laws provide the perfect opportunity for the WTO Dispute Settlement Body to finally engage with the range of interests clearly identified as the 'Objectives' of the TRIPS Agreement. 